\title{
The United States as Nation-Builders in Afghanistan: Success or (Neoconservative) Failure?
}

\author{
Stefan Hechl \\ Kerngebiet: Zeitgeschichte \\ eingereicht bei: Günter Bischof, PhD \\ eingereicht im Semester: SoSe 2016 \\ Rubrik: SE-Arbeit
}

\section{Abstract deutsch}

Die USA als Nation-Builders in Afghanistan: Ein Erfolg oder (neokonservatives) Scheitern?

Nach den Terrorangriffen am 11. September marschierten US-amerikanische Truppen in Afghanistan ein und besiegten das Talibanregime mit dem Ziel, ein demokratisches System in Afghanistan zu etablieren. Aufgrund unterschiedlichster Fehler war das nation-building jedoch nicht erfolgreich, was zu Aufständen derTaliban führte und den Afghanischen Krieg noch um mehrere Jahre hinauszögerte. Als Gründe für dieses gescheiterte nation-building werden unter anderem die Ausblendung der Geschichte und der vorhandenen sozialen Strukturen des Landes gesehen. Zudem wirkte sich auch der neokonservative Ansatz, der von der Bush-Administration während der ersten Amtszeit Präsident Bushs in Bezug auf nation-building verfolgt wurde, negativ auf den Prozess aus. Insgesamt wurden nicht genügend Ressourcen in den Wiederaufbau Afghanistans investiert und das Resultat des nation-building ist, verglichen mit anderen erfolgreichen nation-building-Prozessen der USA, nicht zufriedenstellend. 


\section{Abstract english}

\section{The United States as Nation-Builders in Afghanistan: Success or (Neo- conservative) Failure?}

The US invaded Afghanistan after the 9/11 attacks and defeated the Taliban regime with the goal of bringing democracy to Afghanistan. However, many mistakes led to ineffective nation-building and a Taliban insurgency, drawing out the Afghanistan War for many years. Reasons include an ignorance of the country's history and social structure, as well as the neoconservative approach to nation-building that was pursued by the Bush administration during Bush's first presidency. Thus, not enough resources were invested into rebuilding Afghanistan and the result is not satisfactory, especially compared to more successful US efforts in nation-building.

\section{Introduction}

As another presidential election looms, many domestic and foreign policy issues are debated and analysed. One of them is Afghanistan: A war that, having started 15 years ago, is now set to become an issue of its third president. Started by George W. Bush junior, whose first presidency saw a relatively fast military victory, the aftermath was later taken over by Barack Obama, who has not managed to completely withdraw from Afghanistan. Will it ever end? If so, how? Comparisons with the Vietnam War are frequent. This paper will look at US attempts of nation-building in Afghanistan - the process that is supposed to transform war-torn countries into functioning, modern states.

It is the contention of many people that despite the frequent assertion that Afghanistan will forever be in a state of internal, tribal war, there is in fact a common Afghan identity, as history has shown. Thus, creating a unified, functioning state after the 2001 invasion would have been possible. However, the US did not commit fully to this task of nation- and state-building in the crucial first phase, mainly due to its ideological approach and an absence of knowledge of the situation. This led to the Taliban insurgency, rendering later efforts useless.

The current state of research seems rather satisfactory, with many authors drawing on Afghanistan's rich history and connecting it to current events. Many articles in journals on political sciences and foreign relations deal with the question of nation-building in Afghanistan, and these can also be used as material in addition to some works from the field of history. Many authors are able to provide first-hand knowledge and experiences, both from US and UN viewpoints, as well as President Karzai representing his view in an interview available in the New York Times. Other primary documents are speeches by George W. Bush and transcripts of his presidential debates with Al Gore in 2000. It should be noted that the primary piece of literature that first inspired this particular topic, and was then used as a basis for further reading, was Jeremy Suri's work Liberty's Surest Guardian. 
After some introductory thoughts on the concepts involved, chapters 3 and 4 will set out some important historical precedent, both regarding past US nation-building efforts and some Afghan history that could have proven invaluable to the occupiers in 2001 and beyond. Chapters 5 and 7 will describe and to a certain extent contrast the policies of the first and second Bush presidencies. Chapter 6 , in between, will examine the US invasion of Iraq, as this is necessary for the understanding of issues that Afghanistan was later confronted with. The paper will then gradually come to an end and conclude with an assessment of the current situation, attempting to define whether at least some success has been achieved in terms of nation-building. The final remarks will look briefly at the Obama administration to round off the issue: Why, at the time of writing, are there still significant numbers of US troops in Iraq? Will this war ever end?

\section{Nation building vs. state building}

There is, evidently, some confusion over, and misuse of, the terms and concepts of nation-building and state-building, which are sometimes used interchangeably while actually describing two rather different things. As defined by lan Bremmer, nationbuilding is used to describe "developing a shared identity"1 while state-building is con-

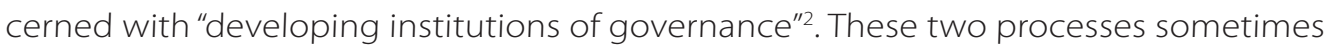
happen simultaneously, but either one can also take place independently of the other. For instance, even in today's Western Europe, there are groups of people that view themselves as nations without having their own state (Scots, Catalans, etc.) as well as states that do not house a single nation (Belgium). Broadly speaking, nation-building takes longer than state-building: In the past, national identities have taken centuries to develop, based on shared history, language and culture. State-building, on the other hand, is often a more concrete process and simply "a matter of effort" ${ }^{3}$.

Darden and Mylonas argue that state-building without nation-building is destined to fail: It does not suffice to merely build roads, train a local police force and then equip them with arms before a foreign occupying power can leave. Instead, effective statebuilding is dependant on legitimacy of rule, loyalty and social cohesion. ${ }^{4}$ Darden and Mylonas identify what they call a "Promethean dilemma"5 as the key issue in successful state-building:

"How can an occupation regime transfer coercive and organizational capacity to the local population while minimizing the risk that those capabilities will be used against its efforts to establish stable governance of the territory?"6

\footnotetext{
1 lan Bremmer, Nation- and State-Building in Eurasia, in: Georgetown Journal of International Affairs, 4 (2003), Nr. 1, p. 29-37, here p. 29 
This issue becomes more and more difficult the smaller the number of troops an occupying nation deploys in the foreign territory.

Hence successful nation-building is not a matter of months or a few years, but of at least a generation. Loyalty and legitimacy have, throughout history, often been created and ensured by institutions such as schools or the church or other factors such as culture and language and been rather successful in creating and implementing a national identity when these processes take place in one's own country (cf. the Habsburg Empire or, even further back, King Alfred's promotion of a common English identity in a time when Britain was divided into several smaller Anglo-Saxon kingdoms). However, occupation of a foreign country on the other side of the world following a war is an immense task that requires complete dedication and the military and financial resources as well as the willingness to stick to a nation-building plan as long as it takes. It will be shown below that this issue is central to the US nation-building effort in Afghanistan.

\section{The US as nation-builders}

It can be argued - as Jeremy Suri has done ${ }^{7}$ - that the United States were one of the first nation-builders when they established themselves as a nation in the $18^{\text {th }}$ century. George Washington himself emphasised the need for a union and its government as a guardian of liberty and prosperity, a model that turned out to be a success and was later implemented in other parts of the world, becoming the standard model of the nation-state: "If you do not have a nation and a state, you do not count in the modern world." 8 With the rise of the US as empire and global power throughout the $19^{\text {th }}$ and $20^{\text {th }}$ centuries, the American model of the nation-state inspired others, but was also implemented directly when the US intervened in other countries, all in the name of global peace and freedom, echoing the right to "Life, Liberty and the pursuit of Happiness" as stated in the Declaration of Independence of 1776.

Starting with the construction of the US itself, then re-construction of the South after the Civil War, nation-building after World War II and in places such as Vietnam, the US has developed a certain approach and creed when it comes to nation-building. While post-WW II nation-building, especially in Germany, can be described as a success, the Cold War era saw a defining moment of US foreign policy: the failure to win the Vietnam War and successfully build a nation modelled on the Western/US model haunts Americans to this day. In the immediate aftermath, President Reagan (a "boisterous advocate of American power" ${ }^{\prime \prime}$ ) was cautious to avoid similar experiences in Lebanon and Libya.

$7 \quad$ Jeremy Suri, Liberty's Surest Guardian. American Nation Building from the Founders to Obama, New York 2011, p. $1-10$.

8 ibid., p. 3.

9 ibid., p. 209. 


\section{Learning from history}

\subsection{Past US nation-building efforts}

"History is the laboratory for nation-building", Jeremy Suri states. As always, it is true that history, while it may not repeat itself, does provide the opportunity to look at problems and events within a longer timeframe and to learn from mistakes while also repeatedly implementing successful strategies. It is no surprise that for the US in Afghanistan from 2001 onwards, the failure in Vietnam a few decades earlier was still looming over military and civilian decision-makers. This resulted in a strategy of extensive attacks from the air, relying on modern technology and high-precision bombing, accompanied by a rather small contingent of ground personnel, while local soldiers and anti-Taliban forces were designed to emphasise legitimacy on the way to a new government and to present Afghans as allies of the US. ${ }^{10}$

Another lesson that should have been taken into consideration is the one already mentioned above: Nation-building is not a matter of a few months - a fact which should have been in plain sight when examining cases of US nation-building such as the reconstruction of the South following the Civil War (essentially lasting from 1863 to 1877) or the occupation of postwar-Germany, lasting from 1945 to either 1949, 1955 or when arguing solely based on sovereignty under international law - up until 1991. It was well known that long-term commitments were necessary and especially Germany had shown how long-term assistance was necessary to support political institutions, the economy and also the education system. The Marshall Plan of 1947 had been a success in Germany, where extensive financial resources had been dedicated to the rebuilding and reconstruction of the country. ${ }^{11}$

\subsection{Learning from Afghan history}

It is not only the US' own history and past nation-building efforts that the US should be aware of when attempting to rebuild and secure Afghanistan. The country itself has a long and eventful history, especially when it comes to conflict and occupation. Socio-political factors are just as important as geographical realities when considering the Afghan situation. The strategically important mountain passes on Afghanistan's southern borders make it the Gateway to India, a location that has always been vital to various military and imperial campaigns, thus there are many military campaigns from the past that one can and should learn from.

It is especially the British, who were part of the invasion force in 2001, that have knowledge and experience of fighting in Afghanistan. General Sir David Richards, chief of the Defence Staff, writes in a foreword to Jules Stewart's 2011 book On Afghanistan's Plains: The Story of Britain's Afghan Wars that the West, and more specifically Britain, has made many mistakes in the course of military action in Afghanistan in the last two centuries.

10 Jeremy Suri, Liberty's Surest Guardian. American Nation Building from the Founders to Obama, New York 2011, p. $228-229$

11 ibid., p. 243-244. 
He stresses the fact that one should aim to find local solutions that take into account the tribal, rural and ethno-linguistic nature of Afghanistan. Richards is rather frank and honest when he states that the Western nation-builders in Afghanistan must "tread cautiously and not try to impose Western values on a highly traditional and largely rural society, even on matters we may find offensive, such as the status of women"12. One can assume that if Richards'strategy had been followed from the start of the occupation, the entire effort could have been rather less tedious and more successful: "Change will come in the longer term, but it will have to come from within, as we are already witnessing in the more cosmopolitan urban centres."13

One decisive factor is Afghanistan's natural rugged landscape with its valleys, deserts and mountains - "natural guerrilla country"14 as David Loyn points out. While the landscape makes it difficult to maintain supply lines for large armies, small ones prove to be ineffective against local resistance forces that are hard to anticipate and difficult to shelter from. The tribal structure of many parts of the country means that mobilisation for resistance fighters is easy, and in the South, the border with Pakistan de facto only exists on maps, making it easy for tribesmen and guerrilla fighters to slip out of the country unnoticed. Foreign invaders have always underestimated Afghanistan: British forces in the First and Second Afghan Wars (1838-1842 and 1878-1880, respectively) thought it would suffice to achieve an initial military victory, install a small occupational force in Kabul and then withdrew to India, leading to slaughter and bloody defeat in both cases. ${ }^{15}$ In 1979, the Soviets believed their military strength would easily allow them to conquer the country, and the US and NATO forces in 2001 thought they would be welcomed by the entire civilian population after having defeated the Taliban. Both assumptions were incorrect and the truth is that while initial military success and successful entrance of the country may seem to be easy to achieve in Afghanistan, "staying and leaving are an entirely different matter"16. Throughout the past 2.000 years, all of the great and less well known conquerors, from Alexander the Great to Ghengis Khan, had to discover that when it comes to Afghanistan, occupation is "not synonymous with subjugation"17.

Apart from the military history of foreign invasions of Afghanistan, one must also look at internal structures of government, especially bearing in mind the argument that is repeated over and over again that Afghanistan, as such a multi-ethnic country, cannot be governed as one state. However, the opposite is true, and one does not even have to look that far back: King Zahir Shah had ruled Afghanistan rather efficiently for four decades until his exile in 1973. He had managed to act as unifying force between the different tribes and ethnicities, reach compromises and command respect among his people. According to Jeremy Suri, Afghanistan had actually been a rather "stable,

12 Jules Stewart, On Afghanistan's Plains. The Story of Britain's Afghan Wars, London 2011, p. xiv.

13 ibid., p. xiv.

14 Christopher M. Wyatt, Afghanistan and the Defence of Empire. Diplomacy and Strategy during the Great Game, London 2011, p. 215.

15 Stewart, Plains, p. xiv-xv.

16 Wyatt, Empire, p. 218.

17 Stewart, Plains, p. xix. 
predictable, even progressive place ${ }^{\prime \prime 18}$ during part of the Cold War, up until a series of coups, the Soviet invasion, the civil war and the Taliban rule. This period, characterised by constitutional government, professional administration, expanding infrastructure and even a growing number of international tourists, meant Afghanistan seemed a reasonably stable and forward-looking country compared to its neighbours at the time. ${ }^{19}$ This era would later give hope to initial nation-building efforts soon after the fall of the Taliban, as it showed that stable government and a reasonably united country had already been possible once.

\subsection{European examples}

In a 2010 article, Sheri Berman argues that late medieval/early modern France can be seen as prime example for successful state-building. She compares the division of Central Europe into many "small political units with vague and porous borders"20 with the situation in Afghanistan and emphasises the role of local religious or political figures. While the reign of the first King of France, Hugo Capet, who came to power in 987, only extended over the regions of Paris and Orléans, monarchs such as Louis XIII (16101643) and Louis XIV (1643-1715) centralised political, military and legal power and established a firm rule of the entire country. ${ }^{21}$ Berman emphasises, in line with what has been argued above, that state-building is a "long, bloody and complex"22 process.

Crucially, her main point is that the challenge of state-building that the US face in Afghanistan is essentially not that different from state-building processes in early modern Europe: The challenge can be subsumed as the replacement of one established sociopolitical order with a new one. This modernisation, as one might call it, has often been a deeply traumatic and difficult experience, but can nevertheless be achieved under the right circumstances. There is no significant reason to believe that the essence of this process has changed over time, but, as Berman puts it, state-building is still "a long, hard slog"23. In the case of the US and Afghanistan, she offers two options: to withdraw and abandon the state-building mission as it would be too much of an effort with no guaranteed success, or to fully commit to the plan and to accept that it will be difficult and lengthy. Key challenges facing US state-builders are, according to Berman, the implementation of government authority in the entire country and the monopolisation of the use of physical force, ${ }^{24}$ as well as dealing with local authorities that stand in the way of this centralisation: in early modern France, these local powers were the nobility and the clergy; in Afghanistan, they are local warlords and the Taliban.25

\footnotetext{
18 Suri, Liberty, p. 233.

19 ibid

20 Sheri Berman, From the Sun King to Karzai: Lessons for State Building in Afghanistan, in: Foreign Affairs, 89 (2010), Nr. 2, p. 2-9, here p. 4.

21 ibid., p. 5.

22 ibid., p. 3.

23 ibid., p. 7.

24 ibid., p. 3.

25 ibid., p. 8.
} 


\section{The Neoconservative approach: George W. Bush, first term}

\subsection{Legitimising the occupation}

Echoing George Washington's idea of the nation-state government being a guardian of liberty, George W. Bush gave a speech to Congress on September $20^{\text {th }} 2001$ in which he interpreted the terrorist attacks on New York and Washington as "freedom itself"26 having been attacked, identifying Al-Qaeda as the attackers and mentioning Afghanistan as a place where Al-Qaeda sent their members to training camps.

"The leadership of al Qaeda has great influence in Afghanistan and supports the Taliban regime in controlling most of that country. In Afghanistan, we see al Qaeda's vision for the world. Afghanistan's people have been brutalized - many are starving and many have fled. Women are not allowed to attend school. You can be jailed for owning a television. Religion can be practiced only as their leaders dictate. A man can be jailed in Afghanistan if his beard is not long enough. The United States respects the people of Afghanistan - after all, we are currently its largest source of humanitarian aid - but we condemn the Taliban regime. It is not only repressing its own people, it is threatening people everywhere by sponsoring and sheltering and supplying terrorists. By aiding and abetting murder, the Taliban regime is committing murder."27

By emphasising the tyranny and oppression by the Taliban and by describing Afghanistan as a failed state that was acting as a safe harbour for terrorists that threatened the US and, indeed, the world, Bush provided legitimacy for direct military intervention. He was backed up in this course of action by NATO, who classified the 9/11 terrorist attacks as military attacks on the US as a NATO member state and thus invoked article 5 for the first time in its history. ${ }^{28}$ In what came to be known as the speech that started the War on Terror, Bush recalled other wars in the history of the US that were started by the need to free foreign peoples of their tyrannical rulers and were followed by programmes of nation-building, specifically mentioning National Socialism and World War II:

"By sacrificing human life to serve their radical visions - by abandoning every value except the will to power - they follow in the path of fascism, and Nazism, and totalitarianism. And they will follow that path all the way, to where it ends: in history's unmarked grave of discarded lies."29

Suri also sees Bush's words as echoes of former presidents Abraham Lincoln, William McKinley, Woodrow Wilson and Franklin D. Roosevelt, all of whom had called for war against evil foreign powers and regimes that threatened not only their own citizens, but the entire world and thus also the US. Placing Islamic extremism in line with

26 George W. Bush, Address to Congress, 20th September 2001, [https://www.youtube.com/watch?v=_CSPbzitPL8], accessed 27th July 2016.

27 ibid.

28 Article 5 of the NATO treaty states that an attack on one member state is an attack on all member states, who will thus collectively help defend the attacked state.

29 Bush, Address to Congress, 20th September 2001 
Fascism and Communism, President Bush found support from large parts of the population, just as many Americans had supported Lincoln's plans in 1861 and those of Roosevelt in $1941 .{ }^{30}$

\subsection{The Bush Doctrine \& Neoconservatism}

The foreign policy of the Bush presidency, especially the question of nation-building, can be clearly split into two parts, separated of course by the monumental day that was $9 / 11$. At the beginning of Bush's first term, he called for a unilateralist and in parts even isolationist foreign policy, clearly marking a change from the Clinton era. After the end of the Cold War, until 9/11, US foreign policy often consisted of merely reacting to events as they occurred. ${ }^{31}$ In his election campaign, Bush also explicitly stated that with him as president, the US would not be engaging in nation-building efforts. ${ }^{32}$ Nationbuilding was an issue in the 2000 presidential debates between George W. Bush and Al Gore. As the following excerpts from two of the debates show, Bush clearly dismisses US nation-building projects, while Gore is supportive of them and uses a comparison between the aftermaths of World War I and World War II to show how US nation-building has helped war-torn countries. In one debate, Somalia is used as an example by Bush:

BUSH: "[Somalia] started off as a humanitarian mission and it changed into a nation-building mission, and that's where the mission went wrong. The mission was changed. And as a result, our nation paid a price. And so I don't think our troops ought to be used for what's called nation-building. I think our troops ought to be used to fight and win war. I think our troops ought to be used to help overthrow the dictator when it's in our best interests. But in this case it was a nation-building exercise, and same with Haiti. I wouldn't have supported either."

GORE: "[...] This idea of nation building is kind of a pejorative phrase, but think about the great conflict of the past century, World War II. During the years between World War I and World War II, a great lesson was learned by our military leaders and the people of the United States. The lesson was that in the aftermath of World War I, we kind of turned our backs and left them to their own devices and they brewed up a lot of trouble that quickly became World War II. And acting upon that lesson in the aftermath of our great victory in World War II, we laid down the Marshall Plan, President Truman did. We got intimately involved in building NATO and other structures there. We still have lots of troops in Europe. And what did we do in the late '40's and '50's and '60's? We were nation building. And it was economic. But it was also military. And the confidence that those countries recovering from the wounds of war had by having troops there. We had civil administrators come in to set up their ways of building their towns back."

30 Suri, Liberty, p. 222-223.

31 Joyce P. Kaufman, A Concise History of US Foreign Policy, Lanham 2010, p. 139-140.

32 ibid., p. 140 
BUSH: "I think what we need to do is convince people who live in the lands they live in to build the nations. Maybe I'm missing something here. I mean, we're going to have kind of a nation building corps from America? Absolutely not. Our military is meant to fight and win war. That's what it's meant to do. And when it gets overextended, morale drops." ${ }^{\prime 3}$

In a different debate, Bush gave a clear commitment to stop nation-building missions around the world:

BUSH: "[...] If we don't stop extending our troops all around the world and nation building missions, then we're going to have a serious problem coming down the road, and I'm going to prevent that." ${ }^{\prime 34}$

Bush was later blamed for completely changing his policies on the topic of nationbuilding, but of course it can be argued that in the light of a monumental event such as the 9/11 attacks, it is entirely justified to change policies. 9/11 changed everything and with the start of the War on Terror, the military was now being used actively as a foreign policy instrument..$^{35}$

In a speech at West Point Military Academy in 2002, President Bush expanded on the foreign policy approach that was developing at the time. Adding to strategy of attacking states that were harbouring terrorists, the Bush Administration was now also asserting its right ${ }^{36}$ and intention to strike pre-emptively against any foreign power that posed a threat to the US. Bush specifically mentioned the fact that while some states may agree to and sign non-proliferation treaties, these provided no guarantee that the foreign power would no longer be a threat to the US, and thus military strikes could become necessary:

"We cannot defend America and our friends by hoping for the best. We cannot put our faith in the word of tyrants, who solemnly sign non-proliferation treaties, and then systemically break them. If we wait for threats to fully materialize, we will have waited too long-Our security will require transforming the military you will lead - a military that must be ready to strike at a moment's notice in any dark corner of the world. And our security will require all Americans to be forward-looking and resolute, to be ready for pre-emptive action when necessary to defend our liberty and to defend our lives."137

Pre-emptive strikes, the War on Terror and a departure from earlier, more formal alliances all made up what came to be known as the Bush Doctrine. This policy was developed further in a series of speeches and then made official in a document called the

33 Presidential Debate between Al Gore and George W. Bush, 11th October 2000, Transcript [http://www.debates. org/index.php?page=october-11-2000-debate-transcript], accessed 27th July 2016.

34 Presidential Debate between Al Gore and George W. Bush, 3rd October 2000, Transcript [http://www.debates.org/ index.php?page=october-3-2000-transcript], accessed 27th July 2016.

35 Kaufman, History, p. 142.

36 cf. Article 51 of the UN Charter - the US is of the opinion that this article (which allows self-defence) can also be invoked pre-emptively.

37 George W. Bush, Graduation Speech at West Point Military Academy, 1st June 2002, [http://georgewbushwhitehouse.archives.gov/news/releases/2002/06/print/20020601-3.html], accessed 27th July 2016. 
National Security Strategy, September 2002. It would later act as basis for justification of war against Iraq in 2003, without formally consulting the international community. ${ }^{38}$

The other aspect of the foreign policy of the early Bush era was its neoconservative approach. The neoconservatives, a school of political thinking whose influence grew and reached a high point during the Bush administration, was represented by many in Bush's inner circle, including Paul Wolfowitz, Paul Bremer, Vice President Dick Cheney and Secretary of Defence Donald Rumsfeld. Dan Caldwell assesses Vice President Cheney as the key architect of foreign policy in the Bush era, with these policies then being implemented as actual programmes by Rumsfeld. ${ }^{39}$ When it came to the invasion and occupation of Afghanistan, the neoconservative approach was to use a rather small occupational force that focussed on specifically targeted interventions while "empowering positive local forces and dismantling their detractors"40.

The neoconservative nation-building strategy aimed at giving some impulses to the local forces and protecting the new government from dangers, but leaving the rest up to the locals. Similarly to the policy of a reduction of government intervention in domestic issues, this neoconservative approach could also be used in foreign policy and led to an underinvestment of resources in Afghanistan. ${ }^{41}$ Neoconservatism in foreign policy, specifically in nation-building, can be summed up as the willingness to intervene, but also the hesitancy to invest substantially in the aftermath, in military, financial as well as economical terms, i.e. maintaining only a light military presence in the region and devoting only small few funds towards the development of the country.

\subsection{From Kabul to Bonn}

The invasion itself commenced only 2 weeks after the 9/11 attacks and was named, rather interestingly, Operation Enduring Freedom. At the beginning, the Bush administration had no plan for a longer occupation of Afghanistan. ${ }^{42}$ Still, the invasion was successful and by November $12^{\text {th }}$, the Taliban had fled Kabul, whose citizens greeted the liberation force (consisting mainly of Afghan anti-Taliban forces, the Northern Alliance, and only a small number of US troops) with enthusiasm compared to that of the Parisians in 1944. ${ }^{43}$ Looking back at history (see above), however, this had been the easy task. Ensuring the enduring freedom promised in the name of the invasion, as well as building a stable and democratic state and society, would now prove to be much harder. However, there continued to be promising signs, especially embodied by a conference that took place at the end of November in Bonn, Germany, with involvement of the United Nations.

38 Kaufmann, History, p. 146.

39 Dan Caldwell, Vortex of Conflict. US Policy Toward Afghanistan, Pakistan, and Iraq, Stanford 2011, p. 192.

40 Suri, Liberty, p. 240.

41 ibid

42 ibid., p. 229.

43 ibid., p. 231. 
The conference was attended by representatives of Afghanistan's four main anti-Taliban factions: from the north, the Tajiks and Uzbeks, who now controlled Kabul; the emigrants that were now allied with Iran, the members of the influential and dominant Pashtun tribe; and the "Rome Group", Pashtuns affiliated with the exiled King Zahir Shah. ${ }^{44}$ Notably, some important groups of Afghan society were absent, such as Pashtun Islamists or the urban and secular Afghans, who were mostly in favour of a united, pro-western Afghanistan. They were, however, viewed suspiciously by the US, as they had mostly stayed in Kabul and other cities during the short Communist period of Afghan history. ${ }^{45}$

Perhaps fondly recalling the aforementioned times of national unity and stability under Zahir Shah, the Afghan representatives in Bonn were in a good mood. James Dobbins, US diplomat, ambassador and in 2013 and 2014 Special Representative for Afghanistan and Pakistan, recalls the atmosphere at the conference:

"Observing the various Afghan delegations' arrival in the previous several days, I had been pleasantly surprised by the warmth with which the members of competing factions had greeted one another. The atmosphere sometimes approached that of an extended family reunion, as indeed it was for some. I wondered if the ethnic and religious divisions within Afghan society might be less deep seated than those I had encountered in the Balkans and would later observe in Iraq."46

The negotiations did, indeed, prove to be constructive. Dobbins'account of the conference makes it clear that on quite a few issues, the Bush administration had no opinion, thus backing up Suri's claim that there was no plan (see above). If there was a plan, it focussed on military aspects and quick victory. Sustained economic and political stateand nation-building was not a priority under the emerging Bush Doctrine, which may be an explanation for the way in which Washington was involved in Bonn. ${ }^{47}$ Hence, some decisions were made at Dobbins own discretion:

"For almost all the issues discussed in Bonn, I had no written instructions and a good deal of leeway. My job was to get an agreement and almost any agreement would do, so long as it resulted in an Afghan government that would replace the Taliban's, unite the opposition, secure international support, cooperate in hunting down al Qaeda's remnants, and relieve the United States of the need to occupy and run the country."48

Dobbins recalls how a member of the Iranian delegation made a pointed remark alluding to Washington's "whatever"-attitude when he asked if the draft for a new Afghan constitution should not include a call for democratic elections and a condemnation of terrorism, two aspects the Bush administration had not yet given much thought to.

\footnotetext{
44 Suri, Liberty, p. 235.

45 Jonathan Steele, Ghosts of Afghanistan. The Haunted Battleground, London 2011, p. 256-257.

46 James F. Dobbins, After the Taliban. Nation-Building in Afghanistan, Washington 2008, p. 77.

47 Steele, Ghosts, p. 261-262.

48 Dobbins, Taliban, p. 85.
} 
Dobbins accepted the proposals nevertheless. ${ }^{49}$ After some debate about the capacity in which the former King Zahir Shah, who had returned from exile, was to be involved in the formation of a new government, an agreement was reached at the beginning of December, formally titled the "Agreement on Provisional Arrangements in Afghanistan Pending the Re-establishment of Permanent Government Institutions".50

The Bonn Agreement determined the establishment of first an Interim Authority which was to convene a so-called Loya Jirga, ${ }^{51}$ then a Transitional Authority, which was to draw up a constitution on the basis of which democratic and free elections could be held. The former king was chosen to formally open the Loya Jirga, thus adding extra symbolic character to emphasise the unity of the country. The Bonn Agreement pledged to respect human rights, the role of women, and that Afghanistan would cooperate with the United Nations in the war on terrorism, drugs and organised crime. The agreement also set out the establishment of the International Security Assistance Force (ISAF), formally set up by a UN Security Council Resolution ${ }^{52}$ and implemented via a NATO mission.

In a way, the Bonn agreement could be described as a success. The different ethnic groups had constructively worked together and committed themselves to end "the tragic conflict in Afghanistan"53 and to promote "national reconciliation, lasting peace, stability and respect for human rights" ${ }^{\prime 54}$. They reaffirmed the independence, national sovereignty and territorial integrity" 55 of Afghanistan. They involved the international community into the process, received pledges for foreign aid and managed to find an interim leader, the Pashtun Hamid Karzai, who was acceptable for all groups and commanded respect and legitimacy as a "trusted elder"56 and arbitrator, similar to King Zahir Shah. All in all, the future was looking bright: the invasion had been a military success and could even be described as a liberation, and the Afghans themselves had agreed to an optimistic plan for the future. It seemed like the neoconservative approach of the Bush administration had worked.

However, the reality is that the results of Bonn might have looked better on paper than they eventually turned out to be. In line with the general reluctance of the US to get involved deeply, the Bush administration placed its hopes on the Northern Alliance, many of whom had "a despotic past"57, hoping to use the military potential of this group for its own needs and goals. The consequences of this strategy were not

\footnotetext{
49 Suri, Liberty, p. 83.

50 Bonn Agreement 2001, 5th December 2001, [http://peacemaker.un.org/afghanistan-bonnagreement2001], accessed 27th July 2016.

51 A Loya Jirga is a traditional meeting of tribal chiefs from all over the country, comparable to a constitutional convention.

52 UN Security Council, Security Council Resolution 1386 (2001) on the situation in Afghanistan, 20th December 2001, [http://www.refworld.org/docid/3c4e94571c.html], accessed 27th July 2016.

53 Bonn Agreement 2001, p. 2.

54 ibid.

55 ibid

56 Suri, Liberty, p. 237

57 Marin Strmecki, It's the Regime, Stupid! The Imperative of State-Building in Afghanistan, in: Georgetown Journal of International Affairs, 4 (2003), Nr. 1, p. 39-47, here p. 39-40.
} 
ideal, however, considering that the Northern Alliance even consciously let Taliban fighters and Osama bin Laden himself escape over the border to Pakistan in exchange for bribes. ${ }^{58}$ The leaders of the Northern Alliance had been bin Laden's mentors in the 1980s. ${ }^{59}$ The moderate "Rome Group" of Pashtuns loyal to the exiled king, on the other hand, was underrepresented at Bonn. Some tentatively suggested that perhaps even moderate Taliban representatives should have been invited to participate at the Bonn conference. Regarding the decision on the interim government, Marin Strmecki suggests that while the Pashtun Hamid Karzai was presented as the wise elder statesman who would be able to hold together the country, the actual power - military, police, intelligence - was all in the hand of Northern Alliance members, who thus dominated the new government. ${ }^{60}$ Steele suggests that by backing Karzai, the US alienated some of its would-be allies in Afghanistan. Quoting Francesc Vendrell, the EU's special representative for Afghanistan, he asserts that Karzai was "hardly a household name". In a way, while Bonn led to problems in the longer term, the US and many in the international community viewed the agreement as an encouraging success on the way to a new Afghanistan.

\subsection{Problems arise}

After the initial success, the US were over-confident and did not commit more thoroughly to ensuring that the initial successes would turn into long-lasting peace. A new government had been installed, but it was lacking basic tools for governance, with the early day chaos already leading to plundering and corruption. ${ }^{61}$ Around the time of the Bonn conference, Bush and Cheney had already started thinking about how the next stage in the War on Terror would be to oust Saddam Hussein in Iraq, anticipating that this would require a large number of US troops. ${ }^{62}$ This plan, together with the general neoconservative strategy of operating with a light footprint, led to what most scholars agree was a fatal error: The US troop size in Afghanistan was smaller than in any other country in which the US were engaged in nation-building efforts since World War Two. Financial aid was also low. A comparison with postwar Germany shows how much the US neglected Afghanistan:63, 64

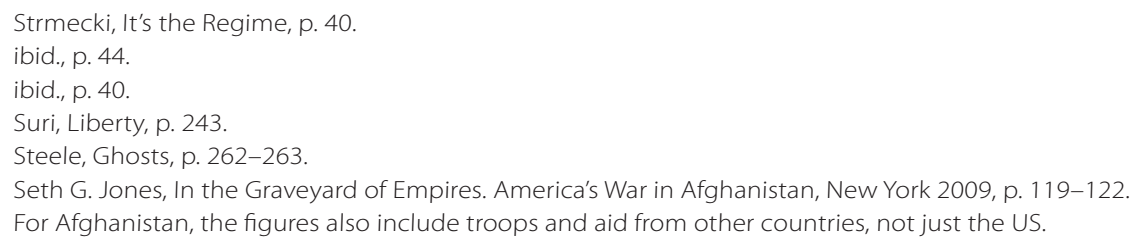




\begin{tabular}{|l|c|c|}
\hline & Germany after WW2 & Afghanistan after 9/11 \\
\hline $\begin{array}{l}\text { Troops deployed per 1.000 } \\
\text { inhabitants }\end{array}$ & 89.3 & 1.6 \\
\hline $\begin{array}{l}\text { Financial assistance per } \\
\text { capita over the initial two } \\
\text { years, adjusted for inflation }\end{array}$ & 129 US $\$$ & 60 US $\$$ \\
\hline
\end{tabular}

The primary objective of the 9.000 US troops (plus 1.200 other international coalition forces) was counterterrorism: to hunt down and capture Taliban and Al-Qaeda extremists. Apart from this goal, there was no reconstruction plan. ${ }^{65}$ Until 2005, troop sizes doubled from 9.000 to 19.000 , but this number was still tiny in comparison with the force of 145.000 US soldiers that invaded Iraq in 2003. ${ }^{66}$ According to the top CIA officer in Afghanistan, Gary Schroen, troops were withdrawn from Afghanistan as early as March 2002 in order to be later used in Iraq - mainly key Special Forces units. He added, and his view was supported by former Deputy Secretary of State Richard Armitage, that the focus on Iraq decidedly weakened the US position and effort in Afghanistan, with Armitage concluding that the US never recovered from this mistake. ${ }^{67}$

The after-effects of the military invasion, coupled with the missing resources (both military and financial), led to a power vacuum that soon opened up, especially in the rural areas of the country. This vacuum was quickly filled by regrouping Taliban loyalists, local warlords, drug barons and members of Al-Qaeda. ${ }^{68}$ The Bush administration did not react. Especially with the upcoming Iraq War in mind, the neoconservatives still supported an early withdrawal from Afghanistan, with Paul Wolfowitz citing British and Soviet experiences as a precedent for the fact that staying too long in Afghanistan might lead to disaster. ${ }^{69}$ Meanwhile, the security of the Afghan people was not guaranteed. Without security, there was no stability, and without stability, the international community started neglecting Afghanistan in terms of financial donations. This absence of financial aid only led to a further increase of corruption within the new interim government.

One thing the US did do, however, was the establishment of Provincial Reconstruction Teams (PRTs) - in a way similar to the over 500 small garrisons used in the Philippines (1899-1902) or the Civil Operations and Rural Development Support (CORDS) programme in the Vietnam War. ${ }^{70}$ The tasks of these PRTs range from building schools and disarming opponents to supporting elections and mediating between local fac-

65 Caldwell, Vortex, p. 173.

66 ibid., p. 172

67 both quoted in Caldwell, Vortex, p. 173.

68 Suri, Liberty, p. 243.

69 Caldwell, Vortex, p. 172.

70 ibid., p. 185. 
tions. ${ }^{71}$ In theory, they were a very good concept. However, lots of potential was wasted in the crucial first phase of reconstruction, again due to the general neoconservative approach and specifically the limited resources. One issue was that the PRTs in Afghanistan consisted almost entirely of military personnel, while civilian institutions such as the State Department did not manage to provide adequate personnel for PRTs. Additionally, there were not nearly enough PRTs in Afghanistan in the period immediately following the defeat of the Taliban: only 8 PRTs in 2003 and 14 in 2004. ${ }^{72}$ This was not enough to extend US presence and reconstruction effort throughout rural Afghanistan. To make things worse, the PRTs often demonstrated "lack of coordination, amateurish efforts, and an ad hoc approach"173 - not at all promising for a successful nation-building programme.

Looking back at history, the US should have immediately started implementing programmes in Afghanistan that had previously been successful in other nation-building or reconstruction efforts. Suri mentions the Freedmen's Bureau in the American South, the Philippine Commission or the immensely successful Marshall Plan as successful reconstruction programmes that could have been repeated, or at least used as inspiration, to ensure peace, stability and democracy in Afghanistan. ${ }^{74}$ The Bush administration did none of these things. History, and recent developments such as the Bonn Agreement, showed that nation-building in Afghanistan would have been possible, but was neglected, perhaps intentionally: "The United Stated destroyed, but it did not rebuild."75

\subsection{Interlude: Iraq}

It is necessary to mention Iraq in this context. Removing Saddam Hussein from power in Baghdad had already been a goal of US foreign policy before the 9/11 attacks: 1998 saw President Bill Clinton signing into law the Iraq Liberation Act with major support from both major parties. ${ }^{76}$ Bush later expanded on the issue by adding weapons of mass destruction into the equation, and more or less immediately straight after 9/11, the administration began planning an invasion (see above). The Iraq campaign immediately overshadowed Afghanistan. Richard Armitage, Deputy Secretary of State at the time, later confessed:

"From day one it was Iraq, Iraq, Iraq. Afghanistan was really an accidental war for much of the Administration. No one wanted to do it. And once it became clear the Taliban was likely to fall, senior Pentagon officials wanted to turn to Iraq as quickly as possible."77

71 Michael J. McNerney, Stabilization and Reconstruction in Afghanistan: Are PRTs a Model or a Muddle?, in: Parameters, 35 (2005), Nr. 4, p. 32-46, here p. 33.

72 Caldwell, Vortex, p. 186.

73 ibid., p. 188

74 Suri, Liberty, p. 245.

75 ibid.

76 Henry Kissinger, World Order. Reflections on the Character of Nations and the Course of History, London 2014, p. 323.

77 Jones, Graveyard, p. 124-125. 
Interestingly, Colin Powell was one of the only major figures to try and put the main focus on Afghanistan. Powell had already previously advocated, in opposition to Bush and Rumsfeld, the use of a far greater number of troops in Afghanistan, in order to secure a decisive and overwhelming victory. ${ }^{78}$ Nevertheless, attention shifted to Iraq and US resources in Afghanistan were soon lacking in all areas: financial aid, military presence, intelligence, diplomacy, and even general attention to the issue. ${ }^{79}$

Just as most in the Bush administration agreed that Iraq was the primary issue, many scholars now agree that this severe lack of attention and resources in Afghanistan proved fatal, especially as it came at a crucial time when basic military victory was assured, but the difficult task of securing peace and stability was only beginning. It can quite probably also be seen as a factor that led to the Taliban insurgency. ${ }^{80}$ This "obsession", 11 as Francesc Vendrell called the US effort in Iraq, led to a spiral of conflict and an overall worsening of the situation. The initial encouraging success was rendered obsolete and things were not looking good at the end of the first Bush presidency.

\section{Increased efforts: George W. Bush, second term}

\subsection{No second Vietnam}

President Bush reportedly closed a meeting on Iraq in 2007 with the words "[i]f we're not there to win, why are we there?" 82 - but these words did not, as Henry Kissinger asserts, demonstrate the "resoluteness of the President's character"83. Bush was not far away from the end of his 8-year-presidency and was starting to realise the implications of the current situation in both Afghanistan and Iraq for himself and his legacy on the one hand, and for his party and its chance of success in the 2008 election on the other. He surely did not want to go down in the history books as "another Lyndon Johnson"84. At that point, simply withdrawing immediately would have been the worst option, so the second Bush administration did what it could to improve the situation. Bush himself admitted that the US would have to take more responsibility, ${ }^{85}$ and the neoconservative approach of light spending and a small footprint was done away with. Additional troops and funding were sent to both Iraq and Afghanistan.

However, the differences between these two theatres of war once again became apparent: Iraq, still in the centre of attention, was put under the command of General David Petraeus, whose strategy for peacekeeping and reconstructing the country was more effective than the one used in Afghanistan. There, it was already too late. Around 2005, both the Taliban and Al-Qaeda had slowly crept back into the country, having been laying low in Pakistan for a couple of years. The Taliban insurgency began and

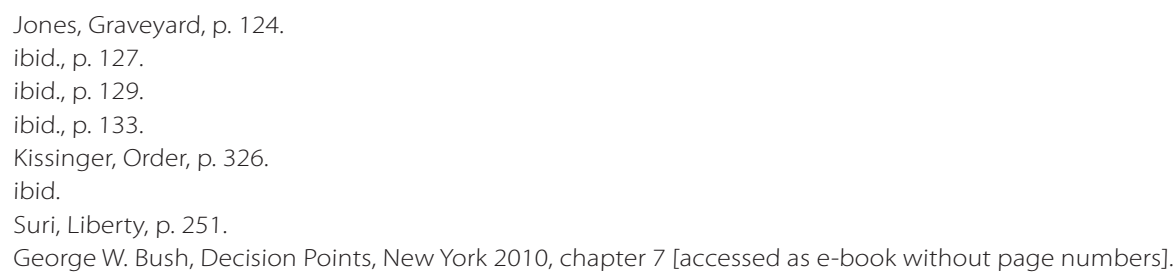


brutally highlighted what the US' failure to efficiently nation-build had led to: In the rural areas of Afghanistan, there was effectively still no security and only ineffective presence of the corrupt central government and military. For many Afghans, the returning Taliban seemed like they were more capable of providing conditions necessary for life in security. ${ }^{86}$ It says rather a lot about the extent and effort of US nation-building in Afghanistan that the Taliban seemed like the better option for many Afghan citizens.

\subsection{Increased efforts?}

While they are of course only one of many aspects of nation-building, the aforementioned Provincial Reconstruction Teams can be an indicator for the intensity of the reconstruction process. While initially only 8 such PRTs operated in Afghanistan in 2003, this number then rose to 22 by 2005 and 26 at the end of Bush's second presidency in $2008 .^{87} 26$ is still a small number, but the rise does indicate a certain increase in the nation-building effort. Military presence increased, but at this stage, the occupation had turned into a counterinsurgency operation, shifting attention of the military to operations against the Taliban. While Kabul continued to turn into a modern urban centre guarded by ISAF rather than the US, most parts of the country did not see actual results in terms of nation-building. Thomas Barfield describes US programmes as mere reconstruction - exemplified in the structurally important ring road around the country that was not rebuilt as a modern highway, but rather literally reconstructed as a narrow and dangerous two-lane road as it had been in the 1960 s. $^{88}$

There were some movements and organisations that were set up to promote democratic values, such as the Welfare Association for the Development of Afghanistan or the Women and Youth for Peaceful Development Organisation, but both of these examples, along with others, were set up by Afghans themselves and received funding from American NGOs, not the government. ${ }^{89}$ The United States Agency for International Development (USAID), a federal government agency, helped fund some independent media outlets with modest grants. ${ }^{90}$ Initiatives like these may have helped give some hope to Afghans about their future, with a 2009 poll finding that a majority approves of the democratic system of government. ${ }^{91}$ However, it must once again be stressed that these developments mainly concern the country's urban centres - while two thirds of the population live in small rural villages.

Some other successes became visible: A study by ACBAR, ${ }^{92}$ a group of aid agencies, published in 2011, found that 80 percent of Afghans now had access to health care,

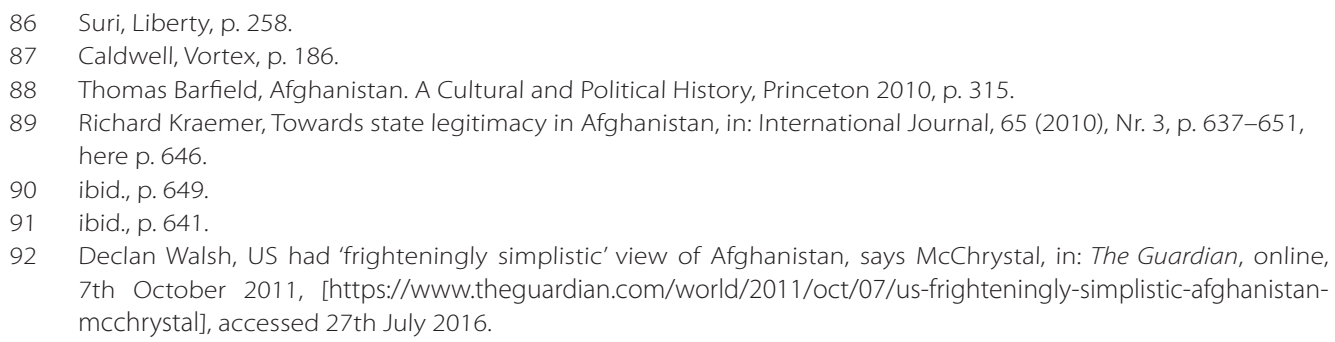
7th October 2011, [https://www.theguardian.com/world/2011/oct/07/us-frighteningly-simplistic-afghanistanmcchrystal], accessed 27th July 2016. 
compared to a staggeringly low 9 percent ten years earlier in 2001. Similarly, the number of children attending school was up from 1 million to 7 million, with the proportion of girls drastically increased. However, illiteracy was still high at 23 percent in 2011. Only 100.000 Afghans were attending university. ${ }^{93}$ In 2010, Transparency International ranked Afghanistan as the third-lowest country in the world in its corruption index, only ahead of Myanmar and Somalia. ${ }^{94}$

What remained a serious problem was the drastic absence of foreign aid. Many Afghans complained that the majority of international aid never led to concrete rebuilding, but rather stayed in the hands of foreign advisors and consultants. ${ }^{95}$ Even in Kabul, the capital and city that profited most from US and international presence, infrastructure like electricity, roads and sewage systems remained below-par and a growing population is settling in slum-like areas on the outskirts of the city. ${ }^{96}$ Vendrell summarised these issues, caused in part by the problem of corruption, as "ineffective reconstruction that hasn't reached the ordinary people.".97

\section{Assessment and outlook}

What was the extent of Bush-era nation-building in Afghanistan? While over the course of this paper, the term "nation-building" has been used as an umbrella term; for this assessment, it is wise to dissect the concept of nation-building into its two narrower meanings, as discussed in the opening chapter.

\subsection{Nation-building}

In terms of nation-building, that is, to construct a common identity for citizens of a country, many saw Afghanistan as an impossible challenge due to its ethnic diversity. However, research shows that this assumption is probably incorrect. US policy makers seem to view Afghanistan with a rather neo-colonial attitude: a backward, third-world failed state in a constant state of internal war and in need of Westernisation and a dose of "freedom". The truth is that Afghanistan is not simply a country of goats, opium and tribal warfare. As mentioned above, especially the 1960s saw real progress and modernity under the reign of Zahir Shah. Kissinger, for instance, seems to ignore this era and frames Afghanistan as the same divided and undemocratic country, not even a state "in the conventional sense" Zahir Shah era and the fact that there is indeed such a thing as an Afghan identity.

This identity seems to have formed over time. Naturally, an Afghan identity cannot be based on ethnicity or language, as these categories are diverse in the country. Al-

93 Michael Daxner, Reclaiming Afghanistan. Moving toward Nationhood?, in: World Policy Journal, 28 (2011), Nr. 2, p. 69-78, here p. 74.

94 Transparency International, Corruption Perceptions Index 2010, [http://www.transparency.org/cpi2010/ results\#CountryResults], accessed 27th July 2016.

95 Steele, Ghosts, p. 296-297.

96 ibid., p. 297

97 qtd. in Steele, Ghosts, p. 299

98 Kissinger, Order, p. 319-320. 
though the term Afghan, first used in the third century A.D., originally applied only to the Pashtuns of the South. Around the start of the $20^{\text {th }}$ century, an Afghan identity began to form around religious and cultural factors. It was developed further by Afghan historiography and by the time of the communist coup, the Afghan identity was so firmly rooted that the new regime did not manage to change the name of the country. The resistance against the Soviet invasion reinforced Afghan identity even further. Along with experiences such as war, flight and emigration, the resistance against "them" invoked a common feeling "us Afghans"99. A 2009 ABC/BBC poll showed that 72 percent of Afghans gave their identity as Afghan first, before their specific ethnicity. ${ }^{100}$ There is no data available, but the historical evidence supports the assumption that the situation was similar or the same in 2001. In 2001, Afghanistan may have been a failed state, but it was not a failed nation. In all the confusion and chaos of the war, there was never a movement to partition the country among ethnic boundaries, similar to what happened in Yugoslavia. To some, this may have been astonishing; to others, it was no surprise. There may have been a lack of political structures, but throughout their history, Afghans had come to realise that their differences were by far outweighed by what united them - they shared a sense of national identity that transcended ethnic boundaries. ${ }^{101}$

What does this mean for US nation-building? Primarily, it means that nation-building in the narrow sense of the word was not really necessary at all in 2001. An Afghan nation existed, and particularly Bonn, despite all its faults, showed that constructive togetherness was possible. The US should have embraced this fact and used it as a basis on which to construct a working state structure. Instead, as described above, Washington put too much hope and trust in specific parts of Afghan society and its political landscape (namely the Northern Alliance). The US had also vetoed giving the exiled King Zahir Shah an actual role in the new government. Instead, he was only given the ceremonial title of Father of the Nation. In this sense, Kissinger is right to say that the vision the US and the other international forces had for Afghanistan was a "radical reinvention of Afghan history"102. Had the US focussed on effective state-building - political institutions, infrastructure, economy - everything might have turned out differently.

\subsection{State-building}

As laid out above, the necessary framework for political institutions was already in place: There was a sense of national identity, which should have been used properly as a basis for a working political system, and Afghans had the experience of reasonably stable government from the Zahir Shah era. During that time, up until 1978, when the communist coup took place, "Afghanistan had maintained a loose federal arrangement

99 Angela Parvanta, Afghanistan - Land of the Afghans?, in: Afghanistan - A Country without a State?, Ed. Christine Noelle-Karimi et. al. (Schriftenreihe der Mediothek für Afghanistan 2), Frankfurt 2002, p. 17-25, here p. 23.

100 Saira Shah, 'Afghaniyat' is alive and well in Afghanistan, in: The Guardian, online, 7th April 2011, [https://www. theguardian.com/commentisfree/2011/apr/07/afghanistan-nation-building-alive-well], accessed 27th July 2016.

101 Barfield, History, p. 277-278.

102 Kissinger, Order, p. 320. 
between a centralized state and semi-autonomous ethnic regions and the Pashtun tribal belt"103. The structure of Afghan politics was primarily one of managing political power and relations between the various factions. ${ }^{104}$ It was only when first the Communists, then the Islamic Mujahedin, and finally the Taliban centralised their rule of the country more and more that governing became ever more difficult ${ }^{105}$ and the relations between the different political and social factions turned violent. ${ }^{106}$ The US, however, aimed at building a strong centralised government that would preside over a democratic Afghanistan from Kabul. Kissinger is right to state that "the efforts required to impose such [centralised] institutions trampled on age-old prerogatives, reshuffling the kaleidoscope of tribal alliances in ways that were difficult for any outside force to understand or control"107. Had Washington looked back at Afghan history, it might have realised that the only viable option was a strongly decentralised, federal state. Instead of condemning the tribal structure, the US should have embraced it and used it as an already existing structure as basis for legitimacy and working government.

The actual process of Bonn, the first Loya Jirga, the writing and adoption of the Afghan Constitution in 2004 and the first elections themselves went quite well. The constitution, in theory, makes Afghanistan a democratic state with a central government. President Karzai said in a 2007 interview with the New York Times that "the political institution-building of the country went very, very well because it was up to the Afghan people to make it a success or not so much success. They made it a success"108. The constitution looks good on paper, but does not reflect reality. Afghanistan is not a centralised state, and some suggest the constitution should be rewritten to turn the country into a federal state, which would be much better suited to its reality. ${ }^{109}$ In the same interview, Karzai articulates his disappointment over the assistance the US had given Afghanistan, especially in political and military terms. Despite the success in building a road network, according to Karzai, even in 2007, electricity was still an issue. He stated that help from the US and other donor countries was needed for this and for other large projects that would revitalise the Afghan economy. ${ }^{110}$ Afghanistan does have lots of potential in economical terms, with many natural resources, the mining of which could provide valuable income for the government. ${ }^{111}$

In terms of lifestyle, some improvements became visible. Michael Daxner, former advisor to the Afghan minister for higher education and member of various UN missions, wrote in 2011 that he had started to find hope and gotten a sense that there was "a genuine movement among Afghans toward taking the initiative and reclaiming a role

103 Ahmed Rashid, Tribe and State in Afghanistan, in: Afghanistan - A Country without a State?, Ed. Christine NoelleKarimi et. al. (Schriftenreihe der Mediothek für Afghanistan 2), Frankfurt 2002, p. 177-178, here p. 175.

104 Strmecki, Regime, p. 42.

105 Rashid, Tribe, p. 175.

106 Strmecki, Regime, p. 42.

107 Kissinger, Order, p. 320.

108 Nicholas Kristof, An Interview with Hamid Karzai, in: The New York Times, online, 1st April 2007, [http://www. nytimes.com/2007/04/01/opinion/01 kristof-transcript.html?_r=0], accessed 27th July 2016.

109 Daxner, Nationhood, p. 76

110 Kristof, Interview.

111 Steele, Ghosts, p. 392. 
in determining their country's future."112 He cited demographic change, urbanisation, the increased access to education (especially for girls) and the emergence of a new middle class as indicators that something, at last, was improving. ${ }^{113}$ However, it must of course be noted - as so often - that these changes mainly only applied to the cities of Afghanistan and often did not extend to the rural areas, where the vast majority of the population was still very poor. It is no coincidence that President Karzai gained a reputation as the "mayor of Kabul"114, since that was as far as his power extended.

\subsection{Bush and Afghanistan: a failure?}

In light of this assessment, can one describe Bush and his administration's mission in Afghanistan as a failure? In retrospect, yes. It is possible to identify five major shortcomings that are responsible for this failure.

Firstly, Afghanistan's rich social, military and political history was largely ignored, despite the invaluable lessons that could have been learnt and used to prevent many problems that later arose. In terms of society, the US should have realised that the Afghan ethnicities, tribes and clans were important and well-established social structures that needed to be treated with respect and caution. They could have been used as basis for a working political system. Regarding this system, the US especially failed to look at the successful reign of King Zahir Shah, who had managed to lead Afghanistan as a federal country by balancing out the interests and demands of the different ethnicities and tribes. Had the US found and emulated his political formula, everything may have turned out to be more successful. The US also failed to anticipate and/or prevent the Taliban insurgency, despite Afghanistan's reputation as a country well-suited for insurgencies and guerrilla warfare. General Stanley McChrystal, in charge of operations in Afghanistan in 2009, in an interview with The Guardian rather openly said that the US had a "frighteningly simplistic"115 view of Afghanistan at the beginning of the war.

Secondly, and related to (or perhaps even the cause of) the first issue, was the attitude of many military and political decision-makers in Washington in regard to the invasion and occupation of Afghanistan in 2001. The neoconservative Bush administration argued for a light footprint in the approach of the invasion, thinking it would be best to defeat the Taliban quickly and with a small force and then allow Afghans themselves to undertake most of the nation-building tasks. This would later prove to be a fatal error and could have been avoided if the US had committed to proper nation-building similar to postwar Germany, with the necessary amount of troops and financial resources. Whether the US simply did not have a proper reconstruction plan, did not have the financial resources, or whether they actually believed the neoconservative, light-footprint approach would work, despite all historical evidence pointing to the opposite, is hard to tell. A quote from a source in the US Department of Defense does,

\footnotetext{
112 Daxner, Nationhood, p. 70

113 ibid., p. 73-74.

114 Shah, Afghaniyat.

115 Walsh, McChrystal.
} 
however, highlight the attitude that led to so many problems in Afghanistan: "It's our job to destroy the enemy and then move on."116

Thirdly, the Bonn conference can be described as one major mistake in the crucial early postwar phase. As a part of the light-footprint strategy, the official US political and diplomatic delegation did not play that much of a role at the conference. Instead, Washington put its hopes in the anti-Taliban Northern Alliance, ignoring its partly radical and despotic past. This policy shifted the balance of power in Bonn. Additionally, some important factions were underrepresented or not represented at all. What the US did do at Bonn, however, was some behind-the-scenes manoeuvring to ensure Hamid Karzai would emerge as leader of the new government. Due to all these factors, the long-term results of Bonn turned out nowhere near as good as the Bonn Agreement had initially suggested. Improvements could have been made if the US had openly participated in the talks as a party, rather than supporting one of them.

Additionally, the Bush and his administration were over-confident after the initial successes of a quick military victory and the Bonn Agreement. This meant, at least in their eyes, that they could continue with the minimalistic approach to nation-building in Afghanistan. Accordingly, the presence of the occupation was mainly confined to the urban centres of the country and soon opened up a power vacuum in the rural areas of Afghanistan. This vacuum was swiftly filled by local warlords and then the Taliban, who had returned from their hiding places in Pakistan. Bush did later realise that Afghanistan was spiralling out of control, but at that point, the Taliban had managed to re-establish a significant presence and the US troops now had to be used to fight the insurgency and ensure basic security, in a stage where nation-building should have been well under way.

Finally, another factor contributed to a lack of personal and financial resources: the Iraq war. The removal of Saddam Hussein had already been on Bush's mind since 9/11 and had in all probability affected military planning for Afghanistan. From the spring of 2003 onwards, all attention was on Iraq and Afghanistan became a secondary matter for Washington, leading to even less effort and resources there. This neglect worsened the situation so much that when Bush finally realised more had to be done in terms of nation-building, the results were far less encouraging in Afghanistan than they were in Iraq.

To be fair, it must be mentioned that Bush partly acknowledged his mistakes. In his 2010 memoir Decision Points, he devoted an entire chapter to the question of Afghanistan. Bush admitted that he had initially been an opponent of the idea of the US participating in nation-building abroad, as has been shown above. However, unsurprisingly, he changed his mind after 9/11 and said he felt the US had a "moral obligation"117 to not only free Afghanistan from its "primitive dictatorship"118, but also to "leave behind

\footnotetext{
116 Strmecki, Regime, p. 46.

117 Bush, Decision Points, Chapter 7.

118 ibid.
} 
something better"119. The rhetoric Bush used - and uses in his memoirs - is grand: He talks of schools, roads, electricity, democracy and peace, and labels Afghanistan as the "ultimate nation-building mission"120. His conclusion is interesting, as it mixes honest truth with one statement that seems puzzling, considering the circumstances and the evidence collected above:

"From the beginning, I knew it would take time to help the Afghan people build a functioning democracy consistent with its culture and traditions. The task turned out to be even more daunting than I anticipated. Our government was not prepared for nation building. Over time, we adapted our strategy and our capabilities. Still, the poverty in Afghanistan is so deep, and the infrastructure is so lacking, that it will take many years to complete the work."121

It can be strongly questioned whether Bush is telling the truth in the first sentence. Actions and quotes from many in his administration point more towards a strategy of getting out of Afghanistan as soon as possible. Had Bush actually acknowledged how much time effective nation-building takes, things might have turned out differently. The rest of his statement, however, is rather surprising in its honesty, especially the assertion that his government was not prepared for such a mission. As Paul D. Miller points out in Foreign Policy, even if Bush had wanted to nation-build properly, it may well be that his people wouldn't have known how. ${ }^{122}$ Bush concluded by stating "I strongly believe the mission is worth the cost"123. One could be inclined to agree that whatever his other motives and even though the execution was somewhat botched, Bush did believe in bringing American-style democracy to some countries in the world that needed it most.

\subsection{Lessons learnt for the future}

Much has been said about the US efforts in Afghanistan, and much can be learnt from them. Perhaps the most important lesson is one that should have already been familiar to American nation-builders, but was not applied from 2001 onwards: Nation-building is almost always a long, complex and costly process. If one is not ready to commit fully to long-term process of nation-building, one might as well drop the plan immediately. Abandoning the project half way through, or knowingly only committing parts of what is actually needed, will do much more harm than good. The US should look back at successful investments like the Marshall Plan and acknowledge that these long-term commitments and investments do pay off. Perhaps it is necessary to ignore the domestic side of such questions, as the electorate may lack the understanding of a nation-building process, but politicians, diplomats and military commanders should certainly not.

\footnotetext{
119 Bush, Decision Points, Chapter 7..

120 ibid.

121 ibid

122 Paul D. Miller, Bush on Nation Building and Afghanistan, in: Foreign Policy, online, 17th November 2010, [http:// foreignpolicy.com/2010/11/17/bush-on-nation-building-and-afghanistan/], accessed 27th July 2016.

123 Bush, Decision Points, Chapter 7.
} 
The US as a country has one of the biggest and perhaps also one of the most successful track records when it comes to nation-building, and it should use this experience to improve its nation-building techniques every single time. Much can be learnt from the reconstruction of the South, from postwar Germany and Japan, and from missions such as Yugoslavia or Somalia. But it is not just its own history the US should learn from, it is also the history of the nation in question. This point in particular could have saved all those involved - Americans, other countries affected by terrorism, and first and foremost Afghans - lots of trouble.

From the particular case of Afghanistan, the US must also learn that when working with a specific country to reconstruct and build a functioning system, the wider picture must not be left out. Afghanistan is of strategic, geopolitical importance and its complex relations with neighbouring states must be taken into account. Pakistan, specifically, proved to be crucial here. Many Taliban fighters escaped across the AfghanPakistani border and hid there for months and years, enabling them to later stage their insurgency. The US must realise that, just as it should have happened in Bonn, everybody needs to be part of the process: all the internal factions, as well as neighbours and other important international bodies who could be relevant or useful to the mission.

Finally, it should be noted that nation-building with a top-down approach is destined to fail in most cases. The US had envisioned a central government for Afghanistan, completely ignoring the country's long tradition of local self-government. Despite the initial joy of the Afghans at being liberated from the Taliban, the imposed central rule, even though it was largely ineffective anyway, gradually led to more and more mistrust of the Americans - who went from being liberators to occupiers to foreigners. The US must ask itself why people in Afghanistan's rural areas turned their backs to Americans and towards the Taliban, a fundamentalist terror regime that nonetheless knew the population and realised what the people wanted and needed. Trust and legitimacy are important for nation-building, and the US should have ensured that these conditions were met.

\subsection{Outlook: Obama and beyond}

Despite all his faults and failures, Bush managed to at least not be remembered as the president who "lost" the Afghanistan war - merely as the one who started it all, and, to be fair, public and international support for the original intervention in 2001 was almost unanimous. Bush then passed on the Afghan problem to his successor, Barack Obama. Despite being called by some the "closest thing to a peace president that the US has elected in a generation"124, Obama did not manage to close the lid on Afghanistan either. Pledging to end the war, Obama deployed a surge of new troops to Afghanistan, peaking at over 90.000 US soldiers around the middle of his first presidency, combined with renewed nation-building efforts and resources for President Karzai to play a me-

124 Spencer Ackerman, Afghanistan decision seals Obama's legacy as the 'twilight war' president, in: The Guardian, online, 15th October 2015, [https://www.theguardian.com/world/2015/oct/15/obama-afghanistan-troops-twilight-war-legacy], accessed 27th July 2016. 
diating role similar to that of King Zahir Shah. ${ }^{125}$ Despite realising the true extent of successful nation-building, according to Suri, Obama made the same mistake as Bush before him: He immediately started off with an exit strategy in mind, thus dooming the mission to fail. ${ }^{126}$ The Taliban continue to fight, along with all the other problems that brings to ordinary Afghan citizens.

In conclusion, Barack Obama also did not manage to end the spiral of conflict that was handed to him by his predecessor. Despite reductions in numbers, US troops remain in Afghanistan throughout 2016. It remains to be seen how his successor will handle Afghanistan, with Hillary Clinton pledging to generally continue Obama's strategy, and Trump going on record saying that the US should withdraw from Afghanistan and rebuild its own country instead. For Afghanistan, this means more corruption, more Taliban insurgencies, more suicide bombings and more death.

\section{Conclusion}

The aim of this paper was to look at US nation-building in Afghanistan from 2001 onwards. The sombre truth seems to be that there was not a lot of nation-building that one could possibly write about. This paper highlighted the run-up to the invasion of Afghanistan in late 2001, which seemed legitimate and was rewarded with initial (military) success. In terms of actual nation-building, though, especially this early phase would have been crucial. A number of reasons got found and highlighted why the US did not nation-build comprehensively, the main reason being the neoconservative agenda of the first Bush administration. It thus seems like the attitude which later led to much trouble in Afghanistan was formed by conscious policy decisions. However, a certain lack of knowledge of Afghanistan's history also contributed to the troublesome first years of the Afghanistan War. Especially the 1960s could have been used as an evidence that a decentralised, federal state would have been the way to set up Afghanistan after the war. Instead, the US wanted to impose a central government which is still struggling to extend its reach to all the rural areas of the country. Nation-building in the narrow sense of the word was, as this paper has shown, not even necessary, as there was in fact a common Afghan identity - a fact that many US decision-makers didn't acknowledge. The war in Afghanistan is not over, but this paper has highlighted some lessons that the US can and should learn and build upon in future nation-building efforts.

\section{Sources}

Bonn Agreement 2001, 5th December 2001, [http://peacemaker.un.org/afghanistanbonnagreement2001], accessed 27th July 2016.

George W. Bush, Address to Congress, 20th September 2001, [https://www.youtube. com/watch?v=_CSPbzitPL8], accessed 27th July 2016. 
George W. Bush, Graduation Speech at West Point Military Academy, 1st June 2002, [http://georgewbush-whitehouse.archives.gov/news/releases/2002/06/print/ 20020601-3.html], accessed 27th July 2016.

Presidential Debate between Al Gore and George W. Bush, 11 th October 2000, Transcript [http://www.debates.org/index.php?page=october-11-2000-debate-transcript], accessed 27th July 2016.

Presidential Debate between Al Gore and George W. Bush, 3rd October 2000, Transcript [http://www.debates.org/index.php?page=october-3-2000-transcript], accessed 27th July 2016.

Transparency International, Corruption Perceptions Index 2010, [http://www.transparency.org/cpi2010/results\#CountryResults], accessed 27th July 2016.

UN Security Council, Security Council Resolution 1386 (2001) on the situation in Afghanistan, 20th December 2001, [http://www.refworld.org/docid/3c4e94571c.html], accessed 27th July 2016.

\section{Bibliography}

Ackerman, Spencer, Afghanistan decision seals Obama's legacy as the 'twilight war' president, in: The Guardian, online, 15th October 2015, [https://www.theguardian.com/ world/2015/oct/15/obama-afghanistan-troops-twilight-war-legacy], accessed 27th July 2016.

Barfield, Thomas, Afghanistan. A Cultural and Political History, Princeton 2010.

Berman, Sheri, From the Sun King to Karzai: Lessons for State Building in Afghanistan, in: Foreign Affairs, 89 (2010), Nr. 2, p. 2-9.

Bremmer, Ian, Nation- and State-Building in Eurasia, in: Georgetown Journal of International Affairs, 4 (2003), Nr, 1, p. 29-37.

Bush, George W., Decision Points, New York 2010.

Caldwell, Dan, Vortex of Conflict. US Policy Toward Afghanistan, Pakistan, and Iraq, Stanford 2011.

Darden, Keith \& Mylonas, Harris, The Promethean Dilemma: Third-party State-building in Occupied Territories, in: Ethnopolitics, 11 (2012), Nr. 1, p. 85-93.

Daxner, Michael, Reclaiming Afghanistan. Moving toward Nationhood?, in: World Policy Journal, 28 (2011), Nr. 2, p. 69-78.

Dobbins, James F., After the Taliban. Nation-Building in Afghanistan, Washington 2008. Jones, Seth G., In the Graveyard of Empires. America's War in Afghanistan, New York 2009.

Kaufman, Joyce P., A Concise History of US Foreign Policy, Lanham 2010. 
Kissinger, Henry, World Order. Reflections on the Character of Nations and the Course of History, London 2014.

Kraemer, Richard, Towards state legitimacy in Afghanistan, in: International Journal, 65 (2010), Nr. 3, p. 637-651.

Kristof, Nicholas, An Interview with Hamid Karzai, in: The New York Times, online, 1st April 2007, [http://www.nytimes.com/2007/04/01/opinion/01 kristof-transcript.html?_r=0], accessed 27th July 2016.

McNerney, Michael J., Stabilization and Reconstruction in Afghanistan: Are PRTs a Model or a Muddle?, in: Parameters, 35 (2005), Nr. 4, p. 32-46.

Miller, Paul D., Bush on Nation Building and Afghanistan, in: Foreign Policy, online, 17th November 2010, [http://foreignpolicy.com/2010/11/17/bush-on-nation-building-andafghanistan/], accessed 27th July 2016.

Parvanta, Angela, Afghanistan - Land of the Afghans?, in: Afghanistan - A Country without a State?, Ed. Christine Noelle-Karimi et. al. (Schriftenreihe der Mediothek für Afghanistan 2), Frankfurt 2002, p. 17-25.

Rashid, Ahmed, Tribe and State in Afghanistan, in: Afghanistan - A Country without a State?, Ed. Christine Noelle-Karimi et. al. (Schriftenreihe der Mediothek für Afghanistan 2), Frankfurt 2002, p. 177-178.

Shah, Saira, 'Afghaniyat' is alive and well in Afghanistan, in: The Guardian, online, 7th April 2011, [https://www.theguardian.com/commentisfree/2011/apr/07/afghanistannation-building-alive-well], accessed 27th July 2016.

Steele, Jonathan, Ghosts of Afghanistan. The Haunted Battleground, London 2011.

Stewart, Jules, On Afghanistan's Plains. The Story of Britain's Afghan Wars, London 2011.

Strmecki, Marin, It's the Regime, Stupid! The Imperative of State-Building in Afghanistan, in: Georgetown Journal of International Affairs, 4 (2003), Nr. 1, p. 39-47.

Suri, Jeremy, Liberty's Surest Guardian. American Nation Building from the Founders to Obama, New York 2011.

Walsh, Declan, US had 'frighteningly simplistic' view of Afghanistan, says McChrystal, in: The Guardian, online, 7th October 2011, [https://www.theguardian.com/world/2011/ oct/07/us-frighteningly-simplistic-afghanistan-mcchrystal], accessed 27th July 2016.

Wyatt, Christopher M., Afghanistan and the Defence of Empire. Diplomacy and Strategy during the Great Game, London 2011. 
Stefan Hechl studies History, English and teacher training at the University of Innsbruck.Stefan.Hechl@student.uibk.ac.at

\section{Zitation dieses Beitrages}

Stefan Hechl, The United States as Nation-Builders in Afghanistan: Success or (Neoconservative) Failure?, in: historia.scribere 9 (2017), S. 99-125, [http://historia.scribere.at], 2016-2017, eingesehen 14.6.2017 (=aktuelles Datum).

(C) Creative Commons Licences 3.0 Österreich unter Wahrung der Urheberrechte der Autorlnnen. 
